\title{
Law Enforcement and Overcoming Violations of Money Politic in General Election: Indonesia's Case
}

\author{
Brian Septiadi Daud ${ }^{1}$, Bayu Ardian Aminullah², Nyoman Serikat Putra Jaya ${ }^{3}$ \\ ${ }^{1}$ Faculty of Law, Universitas Diponegoro, Indonesia \\ septiadybrian@gmail.com \\ 2 Faculty of Law, Universitas Diponegoro, Indonesia \\ bayuardian94@gmail.com \\ 3 Faculty of Law, Universitas Diponegoro, Indonesia \\ putrajaya1984@yahoo.co.id
}

\section{Abstract}

Introduction to The Problem: The election is a way to choose leaders in both the legislative and executive fields. An election mechanism is also a form of power distribution and its limitation, so elections are an important activity for national development. Through this election, there are evil sparks that can be lit by those who have an evil character; one of these sparks is money politics. Therefore, the implementation of elections required law enforcement agencies to deal with election violations and election disputes under applicable rules.

Purpose/Objective Study: The purpose of this study is to find out how law enforcement in violations of money politics in Indonesia and how to deal with its violations.

Design/Methodology/Approach: This article is a doctrinal one and using normative legal research methods with a statutory approach. The statutory course referred to is an approach based on legal reviewers related to the problem being discussed.

Findings: In this study, the authors found that law enforcement of money politics in general elections in Indonesia must be based on established conditions. Such conditions are like implementing the regulations and force them to be implemented right away. Efforts that must be made in overcoming this violation in general elections in Indonesia are by making pre-eventive efforts. These efforts address election violations from the preparation step until the election implementation step. The second act is preventive actions, namely prevention efforts or non-penal measures before election crime. The third is a repressive effort that deals with corruption and focuses on the nature of the action, eradication, or suppression after the crime.

Paper Type: Research Article

Keywords: Law Enforcement; General Election; Money Politics

\section{Introduction}

The State of Indonesia is based on Pancasila and the 1945 Constitution of the Republic of Indonesia. Article 1 paragraph (3) of this Constitution states that "The State of Indonesia is a state of law" (Kenedi, 2018). The provisions in the article state that law is the only basis that has a function as a control and guides in people's lives to create a safe, secure, and fair experience for the nation and state with guaranteed legal certainty. It is clear, in this case, 
that law is the order of national life both in the political, economic, social, and cultural fields, as well as in defence and security.

The era of globalization and the development of science and technology bring positive impacts in all fields. However, despite this positive side, it also has drawbacks to this development. The adverse effects due to this development lead to the crime's mutation. Thus, the developed-crime must be fought against for reducing its spread in the community. One of the tools to overcome these evil doings is through criminal law. The law would enforce its regulation to be applied in all society (Sulchan, 2014).

One of the social fields is the preservation of democracy through the general election to realize people's sovereignty (Kartini, 2017). The election is a way to choose leaders in both the legislative and executive fields. An election mechanism is also a form of power distribution and its limitation, so elections are an important national development (Putri, 2015). Through this election, there are evil sparks that can be lit by those who have an evil character; one of these sparks is money politics. Therefore, the implementation of elections required law enforcement agencies to deal with election violations and election disputes under applicable rules (Ananingsih, 2016). The legality of elections in Indonesia, regulated in Law no. 7 of 2017 concerning General Elections (Election Law). Systematically, the provisions regarding money politics can be found in Book V Chapter II under the heading Election Criminal Provisions in Article 523 paragraph (1-3) (Satria, 2019).

Based on the above description, the formulation of the problem in this paper was divided into two. First, how is law enforcement in money politics as a crime in general elections in Indonesia? Second, how are the efforts to tackle these violations in Indonesia?

\section{Methodology}

This study, qualitatively, employed a normative legal research method. The statutory approach was used within this investigation through legal review related to the discussed problem. Thus, data were obtained from legal material or legal documents. It was then analyzed qualitatively through literature or library research.

\section{Results and Discussion}

The violations within the general election seriously tarnish the people's sovereignty, where they have the right to vote freely without coercion or temptation. We could say that, famously, money politics is dirty means to force the people's vote. Generally speaking, the election corruption has three categories of violations: administrative offences, criminal violations, and violations of ethical election codes (Nail, 2019). Another saying that describes the money politics is a bribery form. It is giving the money to determine one's position, policies to be issued, and political decisions that are benefitting only for personal, group, or political party interests (Lukmajati, 2016).

Money politics is an effort to influence others, in this case, the community, by using material rewards or can also be interpreted as buying and selling votes in the political process and power as well as the act of distributing money, both personal or party property to influence 
the votes of voters (Asnawi, 2018). It can also be referred to as someone who gives a reward or influences someone by providing a sum of money to get more votes in an election.

The practice of money politics is an unlawful act and described as a crime. Still, the public does not care and even wants to accept all types of the material provided by the nominating party (Anggraeni \& Ramdhani, 2018). Indonesia has direct experience of this illegal act that the nominees usually have several strategies when employing money politic as their evil tool, including:

a. Dawn Attack

The dawn attack is a term used to refer to a form of money politics to buy votes made by one or several people to win a candidate who will occupy a position as a political leader. Dawn attacks generally target the lower middle class and often occur before elections.

b. Mass Mobilization

Mass mobilization is a common thing during campaigns that luring society with a sum of money to attend live campaigns organized by a political party. The use of money is usually for transportation costs, tip money, and food allowance, hoping that the masses who come during the campaign will vote for them (Asnawi \& Mulyana, 2018).

\section{Law enforcement in election violation through money politics in Indonesia}

Indonesia habitually using a procedural approach to enforce the law. This legal process model is a judicial concept that guarantees the value of justice based on strict procedures in monitoring and evaluating the performance of law enforcement. It is hoped that this law enforcement process will provide more justice based on the principles of moral justice (Widodo, 2012). Law enforcement, according to Jimly Asshidiqie, is the centre of all legal life activities ranging from legal planning, legal formation, law enforcement, and legal evaluation. It is an intervention between various human behaviours that represent interests within the agreed framework (Sina, 2015).

The requirement of regulations or rules to overcome the wrongdoings is understandable. Thus, the existence of money politics in general elections draws the government to set the rules to cut its living political habit. Indonesian government then publish the Act No. 7 of 2017 on General Elections (Kalakoe et al., 2020). It is directly, as seen in article 523, paragraph (1) to paragraph (3), forbidding the very existence of money politics. Along with the prohibition also sanctions that will be applied to the offenders. Through this regulation, law enforcement is expected to be carried out effectively to prevent election violations, especially money politics. Election offence is blackening the validity of clean and fair elections. So it is necessary to take strict action under applicable regulations to provide a red effect for money politics (Norman, 2019).

The things that need to be considered in law enforcement of money politics are as follows:

1. Ensure that every action, procedure, and decision-related to the election process is following the legal framework;

2. Protect or restore the right to vote; 
3. Allow citizens who believe that their ballot has been violated to submit complaints to the authorities.

\section{Efforts to tackle violations of money political elections in Indonesia}

In dealing with election violations such as money politics, various kinds of countermeasures are needed, such as initial efforts to prevent criminal acts (pre-eventive), pre-crime prevention, and preventive measures after the crime (repressive).

a. Pre-Eventive Efforts

Pre-eventive efforts could be meant as overcoming the money politics in the pre-stage and implementation stage of the general election. General Election Commission must carry out this preventive action and the Supervisory Board of General Election (A.T et al., 2008). The candidate who is found to have violated the election in the form of money politics will be sanctioned with, or the consequences of conducting money politics will be cancelled as a candidate in the general election (Sugiharto, 2016).

All aspects must prevent violation opportunities in election time; for example, the community must have curiosity when the candidate distributes food or money to the community. As a smart community, they will not immediately accept the candidate offer, but ask the goals and intentions of the candidate first. If the community has rejected the basic needs of the candidate pair, then automatically, the purpose of the candidate pair to do money politics will be lost.

b. Preventive Efforts

Preventive efforts are also said to be non-penal efforts because these preventive efforts or prevention efforts are carried out before the crime (Firmansyah, 2011). Handling of money politics is done to prevent the occurrence or emergence of the first crime. Preventing criminal offences is better than trying to educate perpetrators to be even better. The watchword in criminology means that efforts to improve the perpetrators of criminal acts need to be addressed and directed so that no recurring crimes occur. It makes sense that precautions are prioritized because anyone can carry them out without particular and economic expertise. Prevention efforts occupy the key and strategic position of all criminal political actions. This prevention effort is to improve certain social conditions. So from a criminal point of view, all prevention activities through that effort have a strategic position, holding key positions that must be intensified.

c. Repressive

Penalty or repressive efforts are efforts to deal with crime and violations, which focus on the nature of the action, eradication, or suppression after the crime. Enforcement efforts are expected to have a deterrent effect on perpetrators so as not to repeat their steps and cause the fear effect for the community not to commit a crime because they must be convicted/acted if caught by law enforcement officers. 
It is expected to have a deterrent effect on candidate pairs, so in the future, the candidate pairs are reluctant to commit violations of money political elections (Kusuma et al., 2019). The role of the community is expected to be smart not to accept money politics, but will immediately report it to the authorities. Money politics from candidates can be convicted under Law No. 7 of 2017 on Elections. Article 280, paragraph (1) states that anyone who deliberately gives or promises money politics can be sentenced to a maximum of 2 years and a maximum fine of 24 million rupiahs. The same criminal act is applied to voters who intentionally receive gifts or promises of money politics. Eradicating money politics indeed cannot reach zero cases, but with the active participation of all elements, namely the apparatus and the public, is expected to minimize/neutralize money politics (Money politic).

\section{Conclusion}

With the description of the results above, it can be concluded that law enforcement carried out against violations of money political elections is to apply the laws and regulations in effect Law No. 7 of 2017 concerning General Elections, effectively to create clean, honest, and fair elections. It will always guarantee that every action, decision, and procedure, related to the electoral process is following the legal framework, protecting or restoring the right to vote, and allowing citizens who believe that their voting rights have been violated to submit complaints to the authorities.

The efforts made in overcoming money politics are through several actions. First is the preeventive attempt, which always oversees the election from the pre-stage to the implementation stage of the election. Second is preventive effort or a non-penal attempt before the violation occurred in the general election. The last is the repressive action that is done after the occurrence of money politics.

\section{References}

A.T, M. T. N. P., Sunarto, \& Raharjo, E. (2008). Upaya penanggulangan politik uang (money politic) pada tahap persiapan dan pelaksanaan Pilkada serentak di Provinsi Lampung. Ponale: Jurnal Bagian Hukum Pidana, 6(4), 1-14. https://doi.org/10.1017/CB09781107415324.004

Ananingsih, S. W. (2016). Tantangan dalam penanganan dugaan praktik politik uang pada Pilkada serentak 2017. Masalah-Masalah Hukum, 45(1), 49. https://doi.org/10.14710/mmh.45.1.2016.49-57

Anggraeni, L., \& Ramdhani, H. (2018). Pencegahan money politic dalam pemilihan umum melalui penguatan kebijakan non penal. Jurnal Komunikasi Hukum (JKH). https://doi.org/10.23887/jkh.v4i1.13660

Asnawi, A. (2018). Penegakan hukum tindak pidana politik uang pemilihan umum legislatif pada masa kampanye di Kabupaten Serang. Jurnal Hukum Mimbar Justitia, 2(2), 765. https://doi.org/10.35194/jhmj.v2i2.30

Asnawi, A., \& Mulyana, A. (2018). Penegakan hukum tindak pidana politik uang pemilihan kepala daerah di Provinsi Banten menurut Undang-Undang Nomor 10 Tahun 2016 Tentang Pemilihan Gubernur, Bupati dan Walikota. Jurnal Hukum Mimbar Justitia, 4(2), 138. https://doi.org/10.35194/jhmj.v4i2.467

Firmansyah, H. (2011). Upaya penanggulangan tindak pidana terorisme di Indonesia. 
Mimbar Hukum, 23(2), 376-393. https://doi.org/10.22146/jmh.16193

Kalakoe, B., Darusman, Y. M., \& Gueci, R. S. (2020). Pencegahan politik uang pada pemilihan kepala daerah dan pemilihan umum. Jurnal Lex Specialist, 1(1). http://openjournal.unpam.ac.id/index.php/jlsp/article/view/6504

Kartini, D. S. (2017). Demokrasi dan Pengawas Pemilu. Journal of Governance. https://doi.org/10.31506/jog.v2i2.2671

Kenedi, J. (2018). Kebijakan kriminal (criminal policy) dalam negara hukum Indonesia: upaya mensejahterakan. Al-Imarah: Jurnal Pemerintahan Dan Politik Islam, 2(1). https://doi.org/http://dx.doi.org/10.29300/imr.v2i1.1026

Kusuma, L. S. T., Zulhadi, Z., Junaidi, J., \& Subandi, A. (2019). Peran Badan Pengawas Pemilihan Umum dalam penegakan hukum Pemilu (studi penanganan pelanggaran Pemilu pada Sentra Gakkumdu Provinsi Nusa Tenggara Barat). Jurnal Ulul Albab, 23(2), 110-116. https://doi.org/https://doi.org/10.31764/jua.v23i2.1733

Lukmajati, D. (2016). Praktek politik uang dalam Pemilu legislatif 2014 (studi kasus di Kabupaten Blora). Politika: Jurnal Ilmu Politik, 7(1), 138-159. https://doi.org/https://doi.org/10.14710/politika.7.1.2016.138-159

Nail, M. H. (2019). Kualifikasi politik uang dan strategi hukum dan kultural atas pencegahan politik uang dalam pemilihan umum. Jurnal Yuridis, 5(2), 245. https://doi.org/10.35586/.v5i2.770

Norman, L. (2019). Pengaruh money politik palam penentukan kualitas pemilu di Indonesia. 1(1), 156-161. file:///C:/Users/ASUS/Downloads/1673-109-2116-110-20191012.pdf

Putri, M. P. (2015). Peran Komisi Pemilihan Umum dalam sosialisasi Pemilu sebagai upaya untuk meningkatkan partisipasi politik masyarakat pada Pemilu Presiden 2014 di Kalimantan Timur. Ejournal.Ilkom.Fisip-Unmul.Ac.Id.

Satria, H. (2019). Politik hukum tindak pidana politik uang dalam pemilihan umum di Indonesia. Integritas : Jurnal Anti Korupsi, 5(1), 1-14.

Sina, L. (2015). Upaya penegakan hukum terhadap tindak pidana korupsi di Kota Samarinda. Masalah-Masalah Hukum, 44(3), 372. https://doi.org/10.14710/mmh.44.3.2015.372-388

Sugiharto, I. (2016). Rekonstruksi penegakan hukum politik uang dalam pemilihan kepala daerah berbasis hukum progresif. Jurnal Pembaharuan Hukum. https://doi.org/10.26532/jph.v3i1.1351

Sulchan, A. (2014). Rekonstruksi penegakan hukum terhadap perkara pidana pemilihan umum berbasis nilai keadilan. Jurnal Pembaharuan Hukum, I(3), 350-359. http://jurnal.unissula.ac.id/index.php/PH/article/view/1496/1163

Widodo, J. P. (2012). Reformasi sistem peradilan pidana dalam rangka penanggulangan mafia peradilan. Jurnal Dinamika Hukum. https://doi.org/10.20884/1.jdh.2012.12.1.200 